\title{
Epidemiology of worldwide spinal cord injury: a literature review
}

Yi Kang ${ }^{1,2, *}$

Han Ding ${ }^{1,2, *}$

Hengxing Zhou ${ }^{1,2}$

Zhijian Wei ${ }^{1,2}$

Lu Liu',2

Dayu Pan ${ }^{1,2}$

Shiqing Feng ${ }^{1,2}$

'Department of Orthopaedics, Tianjin Medical University General Hospital,

${ }^{2}$ Tianjin Neurological Institute, Key

Laboratory of Post-Neuroinjury

Neuro-repair and Regeneration in

Central Nervous System, Ministry

of Education and Tianjin City, Tianjin,

People's Republic of China

*These authors contributed equally to this work
This article was published in the following Dove Press journal:
Journal of Neurorestoratology

Study design: A literature review of worldwide epidemiology of spinal cord injury (SCI).

Objectives: To review the epidemiological indicators of SCI, such as incidence, prevalence, demographic characteristics, etiology, level and severity of injury, complications and mortality. Setting: The Department of Orthopaedics, Tianjin Medical University General Hospital, Heping District, Tianjin, People's Republic of China.

Methods: We searched articles published in PubMed, Medline, EMBASE and the Web of Science between January 1993 and June 2017 using the key words "spinal cord injury", "traumatic spinal cord injury", "non-traumatic spinal cord injury" and "epidemiology". The incidence, etiology, prevalence, patient demographics, level and severity of injury, complications and mortality were reviewed from the articles.

Results: The epidemiology of SCI has changed. Motor vehicle accidents and falls have become the most common reasons of injury gradually. Incidence of SCI varies by regions or countries, and it has gradually increased with the expansion of human activities. The number of male patients were significantly more than female, the average age of patients with SCI had a tendency to increase gradually. The cervical level of spine was the most common part of injury; there were more number of patients with tetraplegia than patients with paraplegia. Electrolyte disturbances, pulmonary infections, urinary tract infections and bedsores were the four most common complications.

Conclusion: We must have a greater understanding of epidemiology to implement more preventative measures. The epidemiology in different regions is of significant difference, which may be resulted from economic, science and technology, medical, geographical and even social conditions. Therefore, we must establish appropriate intervention measures according to the particularity of population.

Keywords: spinal cord injury, etiology, incidence, patient demographics, complications

\section{Introduction}

Spinal cord injury (SCI) is a kind of high disabling injury; it not only can lead to damage or loss of sensation and motor function, but also may lead to multiple organ dysfunction. Although some treatment methods such as cell therapy have played a beneficial clinical effect, there is no effective measure to cure SCI. ${ }^{1}$ Its expensive treatment cost, long recovery treatment and the loss of labor force always bring great influence to the individual and family, and also bring a heavy burden on the society. Accordingly, a coordinated multisystem approach must be taken into consideration to treat the injury itself and the accompanying complications. ${ }^{2}$

Traumatic spinal cord injury (TSCI), one of the most devastating kinds of injury, may lead to different degrees of paralysis, loss of sensory and dysfunction of bladder
Correspondence: Shiqing Feng Department of Orthopaedics, Tianjin Medical University General Hospital, I54 Anshan Road, Heping District, Tianjin 300052, People's Republic of China

$\mathrm{Tel} / \mathrm{fax}+862227183812$

Email sqfeng@tmu.edu.cn 
or bowel. TSCI not only affect one's health, but also generates a huge economic burden on the family and society. ${ }^{3}$

Non-traumatic spinal cord injury (NTSCI) is a special type of SCI that is not caused by traumatic reasons. The etiologies of NTSCI include vertebral spondylosis (spinal stenosis), tumorous compression, vascular ischemia and congenital disease. ${ }^{4-6}$

No matter TSCI or NTSCI, the economic burden has become an increasingly important concern for individuals and for society at large. It has been reported that the estimated SCI-associated lifetime economic burden ranged from US\$1.47 million to US\$3.03 million per patient in Canada, from those who suffered incomplete paraplegia to who underwent complete tetraplegia. ${ }^{7}$

The purpose of this review was to describe the epidemiological characteristics of SCI in the world in order to increase prevention awareness of individuals and society to determine the incidence of SCI and analyze the epidemiological changes with the development of economy and medical technology.

\section{Methods}

\section{Search strategy}

We searched articles published in PubMed, Medline, EMBASE and the Web of Science between January 1993 and December 2017 using the keywords "spinal cord injury", "traumatic spinal cord injury", "non-traumatic spinal cord injury", "epidemiology". The incidence, etiology, prevalence, patient demographics, level and severity of injury, complications and mortality were reviewed from the articles.

\section{Inclusion criteria}

This review only included papers on human beings and that were published in English. Studies had to describe an original study involving SCI and report SCI epidemiological data. In addition, meeting abstracts, case reports and editorials were excluded from our review.

\section{Data extraction}

Two of the authors reviewed all the titles and abstracts independently and screened according to the inclusion criteria strictly. We explored studies that contained regional or national data on SCI epidemiology. All the references of included literatures were also screened systematically. From all the studies included, the following data were extracted: etiology, incidence, prevalence, patients' demographics, level and severity of injury, complications and mortality of SCI. From the included articles of patients' demographics, the following data were collected: age distribution, male:female ratio and occupations of patients.

\section{Results \\ Etiology}

There are diverse causes of SCI, including falls (falls from height, simple falls), motor vehicle accidents (MVAs)/motor vehicle crashes, sports-related accidents, violence and other remaining causes of injury. Certain differences exist between regions or countries. MVAs and falls are the most common causes of injury accounting for nearly equal percentages (Table 1). ${ }^{8-10}$ The main cause of SCI in developed countries used to be MVAs, but in recent researches, it turned to be falls. However, the most common cause of SCI in nondeveloped countries was still falls. ${ }^{11-18}$

\section{Incidence}

The incidence rate represents the ratio of a new disease in a particular population during a certain period of time. With the expansion of human activities, the incidence of SCI also increased gradually (Table 1). The incidence varied from $13.0^{19}$ per million to $163.4^{20}$ per million people. Among them, the incidence rates of developed countries ranged from $13.1^{21}$ to $163.4^{20}$ per million people. The rates of nondeveloped countries varied from $13.0^{19}$ to $220.0^{22}$ per million people.

\section{Prevalence}

On one hand, incidence reflects the control level of SCI and the possible requirement for improved prevention, and on the other hand, prevalence poses a challenge to health care and even personal and social resources. ${ }^{23}$ Only 3 articles represented prevalence of SCI and 2 articles reported prevalence from $490^{24}$ to $526^{25}$ per million population among developed countries. As for nondeveloped countries, only 1 article reported prevalence of about $440.0^{26}$ per million people. One article represented that the total NTSCI prevalence rate was 367.2 per million in Australia. ${ }^{27}$

\section{Patients' demographics}

As demonstrated in Table 1, the numbers of males were always more than the number of females among the SCI patients. The male:female ratio ranged from $1.10: 1^{28}$ to 6.69: $1^{21}$ among developed countries. As for nondeveloped countries, the ratio varied from $1.00: 1^{26}$ to $7.59: 1{ }^{29}$ The mean age of SCI in developed countries ranged from $14.6^{30}$ to $67.6^{31}$ years. With regard to nondeveloped countries, the average age in articles varied from $29.5^{32}$ to $46.0^{33}$ years. 
Table I Incidence, prevalence, etiology and patients' demographics of SCI

\begin{tabular}{|c|c|c|c|c|c|c|c|c|}
\hline Study & Country (region) & Period & Incidence & Prevalence & $\begin{array}{l}\text { Leading } \\
\text { causes }\end{array}$ & $\begin{array}{l}\text { Second } \\
\text { causes }\end{array}$ & Mean age & Sex ratio \\
\hline Montoto-Marqués et al ${ }^{12}$ & Galicia, Spain & $1995-2014$ & 2.17 & $\mathrm{~N}$ & Falls & MVCs & 50.2 & $3.24: 1$ \\
\hline Tașoğlu et al ${ }^{14}$ & Turkey & $2013-2014$ & $8.1-21.3$ & $\mathrm{~N}$ & Falls & MVCs & 38.3 & $2.31: 1$ \\
\hline Oteir et $\mathrm{al}^{28}$ & Victoria, Australia & $2007-2012$ & $\mathrm{~N}$ & $N$ & Falls & MVCs & 51.0 & I.I0:I \\
\hline Ning et $\mathrm{al}^{45}$ & $\begin{array}{l}\text { Chongqing, People's } \\
\text { Republic of China }\end{array}$ & $2009-2013$ & $\mathrm{~N}$ & $\mathrm{~N}$ & Falls & MVCs & 45.6 & 4.33:1 \\
\hline McCaughey et $\mathrm{al}^{50 *}$ & Scotland & $1994-2013$ & 0.4 & $\mathrm{~N}$ & $\begin{array}{l}\text { One stab } \\
\text { wound }\end{array}$ & $\begin{array}{l}\text { Multiple } \\
\text { wounds }\end{array}$ & 30.0 & $33.48: 1$ \\
\hline Majdan et $\mathrm{a}^{51}$ & Austria & $2002-2012$ & 17.0 & $\mathrm{~N}$ & Falls & $\begin{array}{l}\text { Injuries } \\
\text { at home }\end{array}$ & $\mathrm{N}$ & $1.86: 1$ \\
\hline Chen et $\mathrm{a}^{52}$ & USA & $2010-2014$ & $\mathrm{~N}$ & $\mathrm{~N}$ & Falls & MVCs & 42.2 & $3.95: 1$ \\
\hline Thompson et $\mathrm{a}^{34}$ & Canada & $2000-2011$ & 16.9 & $\mathrm{~N}$ & MVCs & Falls & 46.2 & $3.95: 1$ \\
\hline Sothmann et $\mathrm{al}^{35}$ & $\begin{array}{l}\text { Cape Town, South } \\
\text { Africa }\end{array}$ & $2003-2014$ & $\mathrm{~N}$ & $\mathrm{~N}$ & MVCs & Violence & 34.0 & $5.25:: 1$ \\
\hline Selassie et $a^{53}$ & South Carolina & $1998-2012$ & 70.8 & $\mathrm{~N}$ & MVCs & Falls & 51.5 & $2.88: 1$ \\
\hline Saunders et $\mathrm{al}^{54 * *}$ & USA & $1998-2012$ & 26.9 & $\mathrm{~N}$ & MVCs & Violence & 16.2 & $2.86: 1$ \\
\hline Sabre et $\mathrm{al}^{22}$ & Estonia & $2005-2007$ & 97.0 & $\mathrm{~N}$ & MVCs & Falls & 44.4 & $4.00: 1$ \\
\hline New et $\mathrm{al}^{24}$ & Australia & $|92|-20||$ & $21.0-32.3$ & 490.0 & $N$ & $\mathrm{~N}$ & $N$ & $2.57-4.00: 1$ \\
\hline Mathur et a $\left.\right|^{55}$ & India & 2000-2008 & $N$ & $N$ & Falls & MVCs & $\mathrm{N}$ & $4.20: 1$ \\
\hline Löfvenmark et al ${ }^{19}$ & Botswana & $2011-2013$ & 13.0 & $N$ & MVCs & Violence & $\mathrm{N}$ & $2.45: 1$ \\
\hline Lehre et $\mathrm{al}^{29}$ & Ethiopia & $2008-2012$ & $N$ & $\mathrm{~N}$ & MVCs & Falls & 31.7 & $7.59: 1$ \\
\hline Jain et a $\left.\right|^{40}$ & USA & $1993-2012$ & 54.0 & $N$ & Falls & MVCs & 50.5 & $2.41: 1$ \\
\hline Chamberlain et $\mathrm{al}^{15}$ & Switzerland & $2005-2012$ & 18.0 & $\mathrm{~N}$ & Falls & Sports & 48.0 & $2.90: 1$ \\
\hline Bellucci et a ${ }^{36}$ & Sao Paulo, Brazil & 2012 & $\mathrm{~N}$ & $\mathrm{~N}$ & MVCs & Falls & 35.2 & $5.54: 1$ \\
\hline Nijendijk et al"I & Netherlands & 2010 & 14.0 & $\mathrm{~N}$ & Falls & MVCs & 62.0 & $2.85: 1$ \\
\hline Katoh et a $\left.\right|^{31}$ & Japan & $2011-2012$ & $|2| .4-1|7|$. & $\mathrm{N}$ & Falls & MVCs & $67.6-64.3$ & $2.65-2.75: 1$ \\
\hline Javadi et al ${ }^{33 * * *}$ & Iran & $1980-1988$ & $N$ & $\mathrm{~N}$ & Bullets & MVCs & 46.0 & $84.0: 1$ \\
\hline Shin et $\mathrm{al}^{38}$ & Korea & 2004-2008 & $\mathrm{N}$ & $\mathrm{N}$ & MVCs & Falls & 43.6 & $2.86: 1$ \\
\hline Shrestha et $\mathrm{al}^{16}$ & Banepa, Nepal & $2008-2011$ & $\mathrm{~N}$ & $\mathrm{~N}$ & Falls & MVCs & $\mathrm{N}$ & 2.77:1 \\
\hline Nwankwo and Uche ${ }^{56}$ & Southeast Nigeria & $2009-2012$ & $\mathrm{~N}$ & $\mathrm{~N}$ & MVCs & Falls & 36.1 & $4.31: 1$ \\
\hline Ibrahim et $\mathrm{al}^{57}$ & Kuala Lumpur & $2006-2009$ & $\mathrm{~N}$ & $\mathrm{~N}$ & MVCs & Falls & 39.0 & $3.35: 1$ \\
\hline Chen et $\mathrm{a}^{58}$ & USA & $2005-2011$ & $\mathrm{~N}$ & $\mathrm{~N}$ & MVCs & Falls & $\mathrm{N}$ & $3.61: 1$ \\
\hline \multirow[t]{2}{*}{ Wu et a $\left.\right|^{59 * * * * *}$} & Tianjin, People's & $2008-2011$ & $\mathrm{~N}$ & $\mathrm{~N}$ & Falls & MVCs & 54.6 & $4.96: 1$ \\
\hline & Republic of China & & & & & & & \\
\hline Sabre et a $\left.\right|^{17}$ & Estonia & 1997-2007 & 39.7 & $\mathrm{~N}$ & Falls & MVCs & 39.0 & 5.45:I \\
\hline Lenehan et $\mathrm{al}^{7}$ & $\begin{array}{l}\text { British Columbia, } \\
\text { Canada }\end{array}$ & $1995-2004$ & 35.7 & $\mathrm{~N}$ & MVCs & Falls & 35.0 & $4.00: 1$ \\
\hline Knútsdóttir et $\mathrm{a}^{25}$ & Iceland & $1975-2009$ & 33.5 & 526.0 & MVCs & Falls & 38.0 & 2.57:1 \\
\hline Alshahri et $\mathrm{al}^{32}$ & Saudi Arabia & $2003-2008$ & $\mathrm{~N}$ & $\mathrm{~N}$ & MVCs & Falls & 29.5 & $7.53: 1$ \\
\hline \multirow[t]{2}{*}{ Ning et $\mathrm{al}^{18}$} & Tianjin, People's & 2004-2008 & 23.7 & $\mathrm{~N}$ & Falls & MVCs & 46.0 & $5.63: 1$ \\
\hline & Republic of China & & & & & & & \\
\hline \multirow[t]{2}{*}{ Li et al ${ }^{9}$} & Beijing, People's & 2002 & 60.6 & $\mathrm{~N}$ & Falls & MVCs & 41.0 & $3.13: 1$ \\
\hline & Republic of China & & & & & & & \\
\hline Hasler et a ${ }^{60}$ & Europe & $1988-2009$ & $\mathrm{~N}$ & $\mathrm{~N}$ & MVCs & Falls & 44.5 & $1.85: 1$ \\
\hline Yousefzadeh et $\mathrm{a}^{61}$ & Iran & $2005-2006$ & $\mathrm{~N}$ & $\mathrm{~N}$ & MVCs & Falls & 38.2 & $2.55: 1$ \\
\hline Qureshi et $\mathrm{a}^{62}$ & Rawalpindi, Pakistan & $200 \mathrm{I}-2008$ & $\mathrm{~N}$ & $\mathrm{~N}$ & Falls & MVCs & 39.1 & $3.38: 1$ \\
\hline Rahimi-Movaghar et $\mathrm{a}^{26}$ & Tehran, Iran & $2003-2008$ & 220.0 & 440.0 & MVCs & Falls & 31.0 & $1.00: 1$ \\
\hline Vitale et $\mathrm{al}^{30 * *}$ & USA & $1997-2000$ & 19.9 & $N$ & MVCs & Falls & 14.6 & $1.08: 1$ \\
\hline Pickett et $\mathrm{al}^{20}$ & Canada & $|997-200|$ & 163.4 & $\mathrm{~N}$ & MVCs & Falls & 42.2 & $2.87: 1$ \\
\hline O'Connor and Murray ${ }^{21}$ & Ireland & 2000 & 13.1 & $\mathrm{~N}$ & MVCs & Falls & 37.0 & $6.69: 1$ \\
\hline Dryden et $\mathrm{a}^{137}$ & Canada & $1994-1996$ & $\mathrm{~N}$ & $\mathrm{~N}$ & MVCs & Falls & 33.0 & $3.37: 1$ \\
\hline Dryden et $\mathrm{al}^{39}$ & Alberta, Canada & $1997-2000$ & 52.5 & $N$ & MVCs & Falls & 35.0 & $2.52: 1$ \\
\hline \multirow[t]{2}{*}{ Wang et $\mathrm{al}^{47}$} & Taiwan, People's & $1986-1995$ & $N$ & $\mathrm{~N}$ & MVCs & Violence & 33.0 & $4.56: 1$ \\
\hline & Republic of China & & & & & & & \\
\hline O'Connor ${ }^{63}$ & Australia & $1998-1999$ & 14.5 & $\mathrm{~N}$ & MVCs & Falls & $\mathrm{N}$ & $3.17: 1$ \\
\hline
\end{tabular}

Notes: *This article reported spinal cord injury caused by stab wounds. **This article reported pediatric traumatic spinal cord injury. ${ }^{* * *}$ This article reported veterans with spinal cord injury. ****This article reported cervical spinal cord injury.

Abbreviations: MVC, motor vehicle crash; N, not mentioned; SCl, spinal cord injury. 


\section{Level and severity of injury}

The cervical level of spine was the most common part of injury in both developed countries and nondeveloped countries (Table 2)..$^{12,19-21,34,35}$ Most articles reported a lower percentage of complete injury than incomplete injury, except 4 studies. ${ }^{16,17,32,36}$ In our review, when classifying the types of disabilities caused by SCI, the tetraplegia was more common than paraplegia in both developed countries and nondeveloped countries except Turkey ${ }^{14}$ and Canada. ${ }^{37}$ Motor-complete injuries (America Spinal Injury Association Impairment Scale [AIS]-A or -B) were more common for patients with traumatic SCI, while there were more motorincomplete injuries (AIS-C or-D) for patients with NTSCI. ${ }^{38}$

\section{Mortality}

In recent years, mortality of patients was still high. Estimations of SCI mortality among developed countries varied from $3.1 \%{ }^{7}$ to $22.2 \%,{ }^{39}$ while mortality in nondeveloped countries ranged from $1.4 \%{ }^{18}$ to $20.0 \%{ }^{19}$ (Table 3 ).

\section{Discussion}

SCI not only affects patients' physical, psychological health and social well-being, but also results in a heavy burden on families, communities and health care systems. Understanding and recognition of SCI epidemiology can help the health care system carry out further preventive measures and better allocate resources for disease management. In addition, by comparing epidemiology trends of SCI along with time in different regions, for example, the increasing trend seen in the US or the decreasing trend in Spain, all kinds of systems can collect feedback information about whether preventative measures worked or not. ${ }^{12,40}$

In our review, we have collected and integrated data, and then compared different aspects of SCI in different regions. Some regularity existed from what we got. There were significant differences in etiology, incidence, prevalence, mortality, patients' demographics or level and severity of injury in both developed and developing countries, which may be caused by economic, science and technology, medical, geographical and even social conditions. For example, Gunshot wounds used to be the main cause of SCI in Brazil before 2003. With the development of economy and the progress of society, the main reason has become MVAs and falls. ${ }^{36}$

As for etiology of SCI, because of the growing aging population, no matter in developing or developed countries, falls gradually tend to be one of the main causes of SCI, challenging social health systems and individual economic pressure.
However, MVAs are still the principal cause in some developed countries, especially after drunk and drugged driving, and even without wearing seat belts, in which major groups are young and middle-aged persons. ${ }^{30,41}$ Nearly all the sporting accidents resulting in SCI occurred in younger patients. ${ }^{34,42}$ In the increasingly stringent social security, the occurrence of violence was declining year by year. ${ }^{36,40}$ At the same time, iatrogenic SCI still cannot be ignored ${ }^{43}$ Normative nursing and medical guidelines are of paramount significance to avoid unnecessary injury.

The incidence and prevalence of SCI have increased along with the expansion of human activity. The incidence rates in developed countries ranged from $13.1^{21}$ to $163.4^{20}$ per million people. The rates in nondeveloped countries varied from $13.0^{19}$ to $220.0^{22}$ per million people. Such a broad range might be due to various sampling methods and scopes of research. Among them, NTSCI accounts for a part of proportion. Because of lack of complete reports, NTSCI has not received widespread attention. ${ }^{44}$ During an economic boom, the annual SCI incidence has increased rapidly. Only 3 articles represented prevalence of SCI and 2 articles reported prevalence from $490^{24}$ to $526^{25}$ per million population among developed countries. As for nondeveloped countries, only 1 article reported prevalence of about $440.0^{26}$ per million people. In clinical epidemiological study, the evaluation of the prevalence of SCI is difficult considering that different researchers do not have a unified standard for the definition of SCI. It is of utmost significance to establish effective safety regulations for the prevention of the injury. Once the injury happens, long-term health insurance is critical for the happiness of the patients. ${ }^{9}$

As for patients' demographics, the male:female ratio ranged from 1.10:128 to $6.69: 1^{21}$ among developed countries. As for nondeveloped countries, the ratio varied from 1.00:126 to $7.59: 1 .^{29}$ The mean age of SCI in developed countries ranged from $14.6^{30}$ to $67.6^{31}$ years. With regard to nondeveloped countries, the average age in articles varied from $29.5^{32}$ to $46.0^{33}$ years. Previous researches have shown that the age of SCI patients trends to be bimodal distribution, the first peak is $15-29$ and the second is over 65 years. ${ }^{8}$ The number of male SCI patients is more than the number of female patients, considering that males are the main undertaker of family and social work. Sometimes, males' communal activities are more frequent and often involved in dangerous activities. Laborers, farmers and the unemployed were 3 SCI groups with high risk. ${ }^{45}$ The etiology of high falls was more probably related to work, resulting in thoracic and complete injury, while the cause of low falls was more likely associated with cervical and incomplete motor dysfunction injury. ${ }^{46}$ It shows that we 
Table 2 Level and severity of injury of SCl

\begin{tabular}{|c|c|c|c|c|c|c|c|c|c|}
\hline Study & Country (region) & $\begin{array}{l}\text { Leading } \\
\text { level }\end{array}$ & $\mathbf{T}(\%)$ & C (\%) & $\begin{array}{l}\text { AIS-A } \\
\text { (\%) }\end{array}$ & $\begin{array}{l}\text { AIS-B } \\
\text { (\%) }\end{array}$ & $\begin{array}{l}\text { AIS-C } \\
(\%)\end{array}$ & $\begin{array}{l}\text { AIS-D } \\
(\%)\end{array}$ & AIS-E (\%) \\
\hline Montoto-Marqués et al ${ }^{12}$ & Galicia, Spain & C4-C5 & 54.7 & 43.5 & 44.3 & 12.6 & 23.5 & 19.6 & 0 \\
\hline Tașoğlu et al ${ }^{14}$ & Turkey & TI2-L2 & 26.3 & 35.1 & 35.5 & 16.4 & 21.4 & 26.3 & 0.4 \\
\hline \multirow[t]{2}{*}{ Ning et $\mathrm{a}^{45}$} & Chongqing, People's & $\mathrm{C} 4-\mathrm{C} 6$ & 54.9 & 39.3 & 39.4 & 8.7 & 21.1 & 30.8 & 0 \\
\hline & Republic of China & & & & & & & & \\
\hline McCaughey et $\mathrm{al}^{50 *}$ & Scotland & Cervical & $\mathrm{N}$ & 42.9 & 22.9 & 20.0 & 34.3 & 20.0 & 2.8 \\
\hline Majdan et $\mathrm{al}^{51}$ & Austria & Cervical & $\mathrm{N}$ & $\mathrm{N}$ & $N$ & $\mathrm{~N}$ & $\mathrm{~N}$ & $\mathrm{~N}$ & $\mathrm{~N}$ \\
\hline Chen et $\mathrm{a}^{52}$ & USA & $\mathrm{Cl}-\mathrm{C} 4$ & $\mathrm{~N}$ & 46.8 & 33.7 & 13.2 & 16.2 & 36.6 & 0.4 \\
\hline Thompson et a ${ }^{34}$ & Canada & $\mathrm{Cl}-\mathrm{C} 7$ & 63.9 & 44.9 & 33.1 & 13.0 & 18.3 & 35.3 & 0.3 \\
\hline \multirow[t]{2}{*}{ Sothmann et $\mathrm{al}^{35}$} & Cape Town, South & Cervical & $\mathrm{N}$ & 31.7 & $\mathrm{~N}$ & $N$ & $\mathrm{~N}$ & $N$ & $\mathrm{~N}$ \\
\hline & Africa & & & & & & & & \\
\hline Selassie et $\mathrm{al}^{53}$ & South Carolina & Cervical & 62.3 & 10.4 & $\mathrm{~N}$ & $\mathrm{~N}$ & $\mathrm{~N}$ & $\mathrm{~N}$ & $\mathrm{~N}$ \\
\hline Saunders et $\mathrm{al}^{54 * *}$ & USA & $\mathrm{N}$ & 41.7 & 17.4 & $\mathrm{~N}$ & $N$ & $\mathrm{~N}$ & $\mathrm{~N}$ & $N$ \\
\hline Sabre et $a^{122}$ & Estonia & $\mathrm{Cl}-\mathrm{C} 4$ & $\mathrm{~N}$ & $N$ & $\mathrm{~N}$ & $\mathrm{~N}$ & $\mathrm{~N}$ & $N$ & $\mathrm{~N}$ \\
\hline Mathur et $\mathrm{a}^{55}$ & India & Cervical & $N$ & $\mathrm{~N}$ & 43.9 & 6.4 & 8.0 & 16.4 & 13.0 \\
\hline Löfvenmark et al ${ }^{19}$ & Botswana & $\mathrm{Cl}-\mathrm{C} 4$ & 59.0 & 61.0 & $\mathrm{~N}$ & $N$ & $\mathrm{~N}$ & $N$ & $N$ \\
\hline Lehre et $\mathrm{al}^{29}$ & Ethiopia & Lumbar & $\mathrm{N}$ & 32.2 & 35.1 & 21.6 & 24.3 & 19.0 & 0 \\
\hline Chamberlain et $\mathrm{al}^{15}$ & Switzerland & $\mathrm{N}$ & $\mathrm{N}$ & 28.3 & 28.3 & 10.5 & 17.9 & 39.7 & 1.3 \\
\hline Bellucci et $a^{36}$ & Sao Paulo, Brazil & Cervical & $\mathrm{N}$ & 66.9 & 66.9 & 10.9 & 8.7 & 10.9 & 2.6 \\
\hline Nijendijk et al"I & Netherlands & $\mathrm{N}$ & 69.2 & 33.5 & $\mathrm{~N}$ & $\mathrm{~N}$ & $\mathrm{~N}$ & $\mathrm{~N}$ & $\mathrm{~N}$ \\
\hline Katoh et a $\left.\right|^{31}$ & Japan & Cervical & $\mathrm{N}$ & $\mathrm{N}$ & $\mathrm{N}$ & $\mathrm{N}$ & $\mathrm{N}$ & $\mathrm{N}$ & $\mathrm{N}$ \\
\hline Javadi et $\mathrm{al}^{33 * * *}$ & Iran & Thoracic & $\mathrm{N}$ & 91.2 & $\mathrm{~N}$ & $\mathrm{~N}$ & $\mathrm{~N}$ & $\mathrm{~N}$ & $N$ \\
\hline Shin et $\mathrm{al}^{38}$ & Korea & $N$ & 60.3 & 41.2 & 42.1 & 13.2 & 21.0 & 23.7 & 0 \\
\hline Shrestha et $\mathrm{al}^{16}$ & Banepa, Nepal & Thoracic & $\mathrm{N}$ & 55.9 & 55.9 & 9.7 & 10.8 & 9.2 & 4.5 \\
\hline Nwankwo and Uche ${ }^{56}$ & Southeast Nigeria & Cervical & $\mathrm{N}$ & $N$ & 47.1 & 11.8 & 22.4 & 17.7 & 1.18 \\
\hline Ibrahim et a ${ }^{57}$ & Kuala Lumpur & $\mathrm{N}$ & 37.0 & 36.0 & 36.0 & 15.0 & 21.0 & 20.0 & $\mathrm{~N}$ \\
\hline Chen et $\mathrm{al}^{58}$ & USA & $\mathrm{Cl}-\mathrm{C} 4$ & $N$ & $N$ & $\mathrm{~N}$ & $\mathrm{~N}$ & $N$ & $N$ & $\mathrm{~N}$ \\
\hline \multirow[t]{2}{*}{ Wu et a $\left.\right|^{59 * * * * *}$} & Tianjin, People's & $\mathrm{C} 5$ & $\mathrm{~N}$ & 5.6 & 5.6 & 16.8 & 18.9 & 58.7 & 0 \\
\hline & Republic of China & & & & & & & & \\
\hline Sabre et al ${ }^{17}$ & Estonia & Cervical & $N$ & 53.0 & 65.5 & & & 23.9 & $\mathrm{~N}$ \\
\hline Lenehan et $\mathrm{al}^{7}$ & $\begin{array}{l}\text { British Columbia, } \\
\text { Canada }\end{array}$ & Cervical & 46.2 & 45.3 & 45.3 & 9.6 & 13.3 & 25.7 & $\mathrm{~N}$ \\
\hline Knútsdóttir et $\mathrm{a}^{25}$ & Iceland & Cervical & 57.0 & 39.0 & $\mathrm{~N}$ & $\mathrm{~N}$ & $\mathrm{~N}$ & $\mathrm{~N}$ & $\mathrm{~N}$ \\
\hline Alshahri et $\mathrm{al}^{32}$ & Saudi Arabia & $\mathrm{N}$ & 53.0 & 51.0 & $\mathrm{~N}$ & $\mathrm{~N}$ & $\mathrm{~N}$ & $\mathrm{~N}$ & $\mathrm{~N}$ \\
\hline \multirow[t]{2}{*}{ Ning et al ${ }^{18}$} & Tianjin, People's & Cervical & 71.6 & 25.2 & 25.2 & 18.2 & 14.7 & 41.9 & 0 \\
\hline & Republic of China & & & & & & & & \\
\hline \multirow[t]{2}{*}{ Li et al ${ }^{9}$} & Beijing, People's & Lumbar & $\mathrm{N}$ & $\mathrm{N}$ & $\mathrm{N}$ & $\mathrm{N}$ & $\mathrm{N}$ & $N$ & $\mathrm{~N}$ \\
\hline & Republic of China & & & & & & & & \\
\hline Hasler et a ${ }^{60}$ & Europe & Lumbar & $N$ & $N$ & $\mathrm{~N}$ & $\mathrm{~N}$ & $\mathrm{~N}$ & $\mathrm{~N}$ & $\mathrm{~N}$ \\
\hline Yousefzadeh et $\mathrm{a}^{61}$ & Iran & TIO-L2 & $\mathrm{N}$ & 34.1 & 34.1 & 65.9 & & & 0 \\
\hline Qureshi et $\mathrm{a}^{62}$ & Rawalpindi, Pakistan & TII-LI & $\mathrm{N}$ & 43.0 & 43.0 & 4.0 & 15.0 & 14.0 & 24.0 \\
\hline Rahimi-Movaghar et $\mathrm{a}^{26}$ & Tehran, Iran & Lumbar & $\mathrm{N}$ & 25.0 & 25.0 & 0 & 50.0 & 25.0 & 0 \\
\hline Pickett et $\mathrm{al}^{20}$ & Canada & Cervical & $\mathrm{N}$ & 35.1 & 35.1 & 11.3 & 33.1 & 28.5 & 0 \\
\hline $\mathrm{O}^{\prime}$ Connor and Murray ${ }^{21}$ & Ireland & C4-C5 & $N$ & 39.1 & 39.1 & 17.3 & 10.9 & 32.7 & 0 \\
\hline Dryden et $\mathrm{al}^{37}$ & Canada & Cervical & 27.9 & 19.4 & $N$ & $N$ & $\mathrm{~N}$ & $N$ & $N$ \\
\hline Dryden et $\mathrm{a}^{39}$ & Alberta, Canada & $\mathrm{C5}-\mathrm{C7}$ & $\mathrm{N}$ & 18.2 & $\mathrm{~N}$ & $N$ & $\mathrm{~N}$ & $\mathrm{~N}$ & $\mathrm{~N}$ \\
\hline \multirow[t]{2}{*}{ Wang et al ${ }^{47}$} & Taiwan, People's & Thoracic & 46.0 & 47.2 & 47.2 & 10.3 & 13.2 & 28.6 & 0.3 \\
\hline & Republic of China & & & & & & & & \\
\hline O'Connor ${ }^{63}$ & Australia & C4-C6 & 57.0 & 37.0 & $\mathrm{~N}$ & $\mathrm{~N}$ & $\mathrm{~N}$ & $\mathrm{~N}$ & $\mathrm{~N}$ \\
\hline
\end{tabular}

Notes: *This article reported spinal cord injury caused by stab wounds. **This article reported pediatric traumatic spinal cord injury. ***This article reported veterans with spinal cord injury. *****This article reported cervical spinal cord injury.

Abbreviations: AIS, America Spinal Injury Association Impairment Scale; C, complete; N, not mentioned; SCl, spinal cord injury; T, tetraplegia; RI, respiratory infections; ED, electrolyte disturbances; UTI, urinary tract infections; PU, pressure ulcer; PE, pulmonary embolism; DVT, deep venous thromboses.

should pay more attention to peasants, laborers and the elderly in the prevention, hospitalization and rehabilitation of SCI.

As for level and severity of SCI, cervical spinal cord was the most commonly injured site in both developed countries and nondeveloped countries. ${ }^{12,19-21,34,35}$ Complete cervical SCI always resulted in severe consequences; most of the victims died on the scene of the accident or on the way to the hospital, and so most cervical SCI patients treated in 
Table 3 Complication and mortality of SCl

\begin{tabular}{|c|c|c|c|c|c|c|c|c|c|}
\hline Study & Country (region) & $\begin{array}{l}\mathbf{R I} \\
(\%)\end{array}$ & $\begin{array}{l}\text { ED } \\
(\%)\end{array}$ & $\begin{array}{l}\text { UTI } \\
\text { (\%) }\end{array}$ & $\begin{array}{l}\text { PU } \\
\text { (\%) }\end{array}$ & $\begin{array}{l}\text { PE } \\
(\%)\end{array}$ & $\begin{array}{l}\text { DVT } \\
\text { (\%) }\end{array}$ & $\begin{array}{l}\text { Depression } \\
(\%)\end{array}$ & $\begin{array}{l}\text { Mortality } \\
\text { (\%) }\end{array}$ \\
\hline Montoto-Marqués et al' ${ }^{12}$ & Galicia, Spain & $\mathrm{N}$ & $\mathrm{N}$ & $\mathrm{N}$ & $\mathrm{N}$ & $\mathrm{N}$ & $\mathrm{N}$ & $\mathrm{N}$ & 11.5 \\
\hline Ning et $\mathrm{a}^{45}$ & $\begin{array}{l}\text { Chongqing, People's Republic } \\
\text { of China }\end{array}$ & 7.0 & 1.9 & 1.3 & 1.9 & $\mathrm{~N}$ & $\mathrm{~N}$ & $\mathrm{~N}$ & 1.4 \\
\hline McCaughey et $\mathrm{al}^{50 *}$ & Scotland & $\mathrm{N}$ & $\mathrm{N}$ & $\mathrm{N}$ & $\mathrm{N}$ & $\mathrm{N}$ & $\mathrm{N}$ & $\mathrm{N}$ & 25.7 \\
\hline Majdan et $\mathrm{al}^{51}$ & Austria & $\mathrm{N}$ & $\mathrm{N}$ & $\mathrm{N}$ & $\mathrm{N}$ & $\mathrm{N}$ & $\mathrm{N}$ & $\mathrm{N}$ & 21.4 \\
\hline Thompson et $\mathrm{al}^{34}$ & Canada & $\mathrm{N}$ & $\mathrm{N}$ & $\mathrm{N}$ & $\mathrm{N}$ & $\mathrm{N}$ & $\mathrm{N}$ & $\mathrm{N}$ & 6.1 \\
\hline Sothmann et $\mathrm{a}^{35}$ & Cape Town, South Africa & $\mathrm{N}$ & $\mathrm{N}$ & $\mathrm{N}$ & $\mathrm{N}$ & $\mathrm{N}$ & $\mathrm{N}$ & $\mathrm{N}$ & 2.2 \\
\hline Selassie et $\mathrm{al}^{53}$ & South Carolina & $N$ & $\mathrm{~N}$ & $\mathrm{~N}$ & $N$ & $\mathrm{~N}$ & $\mathrm{~N}$ & $\mathrm{~N}$ & 19.8 \\
\hline Saunders et al ${ }^{54 * *}$ & USA & $\mathrm{N}$ & $\mathrm{N}$ & $\mathrm{N}$ & $\mathrm{N}$ & $\mathrm{N}$ & $\mathrm{N}$ & $\mathrm{N}$ & 5.0 \\
\hline Löfvenmark et al ${ }^{19}$ & Botswana & $\mathrm{N}$ & $\mathrm{N}$ & $\mathrm{N}$ & $\mathrm{N}$ & $\mathrm{N}$ & $\mathrm{N}$ & $\mathrm{N}$ & 20.0 \\
\hline Lehre et $\mathrm{a}^{29}$ & Ethiopia & 5.6 & $\mathrm{~N}$ & 13.5 & $\mathrm{~N}$ & $\mathrm{~N}$ & I.I & $\mathrm{N}$ & 17.1 \\
\hline Jain et $\mathrm{al}^{40}$ & USA & $\mathrm{N}$ & $\mathrm{N}$ & $\mathrm{N}$ & 4.55 & 1.5 & 2.93 & $\mathrm{~N}$ & 7.5 \\
\hline Javadi et $\mathrm{al}^{33 * * *}$ & Iran & $\mathrm{N}$ & $\mathrm{N}$ & $\mathrm{N}$ & 10.65 & $\mathrm{~N}$ & $\mathrm{~N}$ & $\mathrm{~N}$ & 5.1 \\
\hline Nwankwo and Uche ${ }^{56}$ & Southeast Nigeria & 7.1 & $\mathrm{~N}$ & 11.8 & 16.5 & $\mathrm{~N}$ & 5.9 & $\mathrm{~N}$ & 11.8 \\
\hline Wu et al $\left.\right|^{59 * * * *}$ & $\begin{array}{l}\text { Tianjin, People's Republic of } \\
\text { China }\end{array}$ & 18.2 & 30.1 & 23.1 & 9.8 & $\mathrm{~N}$ & 4.9 & $\mathrm{~N}$ & 4.2 \\
\hline Lenehan et $\mathrm{al}^{7}$ & British Columbia, Canada & $\mathrm{N}$ & $\mathrm{N}$ & $\mathrm{N}$ & $\mathrm{N}$ & $\mathrm{N}$ & $\mathrm{N}$ & $\mathrm{N}$ & 3.1 \\
\hline Knútsdóttir et $\mathrm{a}^{25}$ & Iceland & $\mathrm{N}$ & $\mathrm{N}$ & $\mathrm{N}$ & $\mathrm{N}$ & $\mathrm{N}$ & $\mathrm{N}$ & $\mathrm{N}$ & 6.3 \\
\hline Ning et $\mathrm{al}^{18}$ & $\begin{array}{l}\text { Tianjin, People's Republic of } \\
\text { China }\end{array}$ & $N$ & $\mathrm{~N}$ & $\mathrm{~N}$ & $N$ & $\mathrm{~N}$ & $N$ & $\mathrm{~N}$ & 1.4 \\
\hline Qureshi et $\mathrm{al}^{62}$ & Rawalpindi, Pakistan & $\mathrm{N}$ & $\mathrm{N}$ & $\mathrm{N}$ & $\mathrm{N}$ & $\mathrm{N}$ & 1.0 & $\mathrm{~N}$ & $\mathrm{~N}$ \\
\hline Rahimi-Movaghar et $\mathrm{al}^{26}$ & Tehran, Iran & $\mathrm{N}$ & $\mathrm{N}$ & $\mathrm{N}$ & 25.0 & $\mathrm{~N}$ & $\mathrm{~N}$ & $\mathrm{~N}$ & $N$ \\
\hline Pickett et $\mathrm{al}^{20}$ & Canada & $\mathrm{N}$ & $\mathrm{N}$ & $\mathrm{N}$ & $\mathrm{N}$ & $\mathrm{N}$ & $\mathrm{N}$ & $\mathrm{N}$ & 7.9 \\
\hline Dryden et $\mathrm{al}^{37}$ & Canada & $\mathrm{N}$ & $\mathrm{N}$ & $\mathrm{N}$ & $\mathrm{N}$ & $\mathrm{N}$ & $\mathrm{N}$ & 28.9 & $\mathrm{~N}$ \\
\hline Dryden et $\mathrm{al}^{39}$ & Alberta, Canada & $\mathrm{N}$ & $\mathrm{N}$ & $\mathrm{N}$ & $\mathrm{N}$ & $\mathrm{N}$ & $\mathrm{N}$ & $\mathrm{N}$ & 22.2 \\
\hline
\end{tabular}

Notes: *This article reported spinal cord injury caused by stab wounds. **This article reported pediatric traumatic spinal cord injury. ${ }^{* * *}$ This article reported veterans with spinal cord injury. ****This article reported cervical spinal cord injury.

Abbreviations: N, not mentioned; SCl, spinal cord injury; RI, respiratory infections; ED, electrolyte disturbances; UTI, urinary tract infections; PU, pressure ulcer; PE, pulmonary embolism; DVT, deep venous thromboses.

hospital were incompletely injured. Traumatic SCI mostly results in complete SCI (AIS-A or B), while incomplete injuries are more common in NTSCI patients (AIS-C or D). ${ }^{38}$ It has been reported that traumatic SCI always causes concomitant injuries, including head injuries, ribs fractures, limb or pelvic fractures and injuries of the rest of body. Extraspinal fractures are relatively common in the simultaneous occurrence of SCI. ${ }^{4,17}$ The fracture occurrence varies by etiology of injury, sex, injury level and even race. Hyponatremia, pulmonary infections, urinary tract infections, bedsores and deep venous thromboses of lower limbs are common among complications in SCI patients. ${ }^{45}$ The understanding of these associated factors will contribute to early recognition of fractures, prevention of complications, facilitate rapid mobilization and promote rehabilitation outcomes among patients with SCI. ${ }^{47}$

As for mortality, with the improvement of medical conditions, it has been stabilized, though still persists at a high level. Estimation of SCI mortality in developed countries varied from $3.1 \%{ }^{7}$ to $22.2 \%,{ }^{39}$ while mortality in nondeveloped countries was relatively low, ranging from $1.4 \%{ }^{18}$ to $20.0 \% .{ }^{19}$ Mortality is significantly related with increasing age. Mortality of SCI patients over 60 years is much higher than that of SCI patients under 60 years of age..$^{20} \mathrm{As}$ for those who reach older age will typically have incomplete or lower level SCI, and will have relatively high degrees of independence and good health. ${ }^{48}$ As reported, the mortality rate was highest within 1 year after SCI. Risk factors for death comprised heart disease, diabetes, lower levels of pulmonary function and cigarette smoking. The most common causes of death were circulatory system diseases (40\%) and respiratory diseases $(24 \%) .{ }^{49}$ Death in SCI patients is a result of the interaction of many factors, we should aim at high-risk groups, especially older and heavier patients to strengthen nurse and treatment, and actively improve the general condition of patients; at the same time, actively manage various complications, such as prevention of respiratory infection and correcting electrolyte disturbances, and so that reduce the mortality of SCI patients.

Despite these comprehensive bioinformatics analyses, the current study presents several limitations. First, we 
found that a large proportion of studies only reported a region or city in which the SCI patients stay, and the data could not be used to infer a nationwide trend. Second, we have not listed enough articles about NTSCI due to the lack of articles referring to NTSCI. Moreover, the difference of case criteria and variable study periods has caused a certain disturbance to our analysis.

Understanding and recognizing the epidemiological characteristics of SCI is indispensable for the optimal allocation of therapeutic resources and to provide more effective medical services to SCI patients. We expected, through our research, to understand the epidemiological characteristics of SCI much better in order to guide clinical practice and reduce social economic burden.

\section{Conclusion}

There have been a lot of changes in the trends of epidemiology of SCI. MVAs and falls are the most common causes of injury. SCI incidence varies by regions or countries. With the expansion of human activities, the incidence of SCI has gradually increased. The prevalence did not change much over time. The number of male patients was significantly more than the number of female patients. The average age of patients with SCI has a tendency to increase gradually. Cervical level of spine was the most common site of injury; patients with tetraplegia were more than those with paraplegia. Moreover, mortality has been stabilized, although still persists at a high level. Therefore, how to further reduce the incidence of SCI and improve prevention and treatment measures to promote the prognosis of SCI patients are the problems that we should study in the future.

\section{Acknowledgments}

This work was supported by the National Natural Science Foundation of China (81501899), the State Key Program of the National Natural Science Foundation of China (81330042), the International Cooperation Program of National Natural Science Foundation of China (81620108018), the Special Program for Sino-Russian Joint Research Sponsored by the Ministry of Science and Technology, People's Republic of China (2014DFR31210), the Key Program Sponsored by the Tianjin Science and Technology Committee, People's Republic of China (13RCGFSY19000, 14ZCZDSY00044), the Science Foundation of Tianjin Medical University for Young Scholar (2014KYQ01) and the Science Foundation of Tianjin Medical University General Hospital for Young Scholar (ZYYFY2014037).

\section{Author contributions}

All authors contributed toward data analysis, drafting and revising the paper and agree to be accountable for all aspects of the work.

\section{Disclosure}

The authors report no conflicts of interest in this work.

\section{References}

1. Huang H, Mao G, Chen L, Liu A. Progress and challenges with clinical cell therapy in neurorestoratology. J Neurorestoratol. 2015;3:91-95.

2. Inman C. Effectiveness of spinal cord injury rehabilitation. Clin Rehabil. 1999;13(Suppl 1):25-31.

3. Pickelsimer E, Shiroma EJ, Wilson DA. Statewide investigation of medically attended adverse health conditions of persons with spinal cord injury. J Spinal Cord Med. 2010;33(3):221-231.

4. Adams RD, Salam-Adams M. Chronic nontraumatic diseases of the spinal cord. Neurol Clin. 1991;9(3):605-623.

5. Dawson DM, Potts F. Acute nontraumatic myelopathies. Neurol Clin. 1991;9(3):585-603.

6. Schmidt RD, Markovchick V. Nontraumatic spinal cord compression. J Emerg Med. 1992;10(2):189-199.

7. Lenehan B, Street J, Kwon BK, et al. The epidemiology of traumatic spinal cord injury in British Columbia, Canada. Spine (Phila Pa 1976). 2012;37(4):321-329.

8. van den Berg ME, Castellote JM, Mahillo-Fernandez I, de Pedro-Cuesta J. Incidence of spinal cord injury worldwide: a systematic review. Neuroepidemiology. 2010;34(3):184-192; discussion 192.

9. Li J, Liu G, Zheng Y, et al. The epidemiological survey of acute traumatic spinal cord injury (ATSCI) of 2002 in Beijing municipality. Spinal Cord. 2011;49(7):777-782.

10. Ning GZ, Wu Q, Li YL, Feng SQ. Epidemiology of traumatic spinal cord injury in Asia: a systematic review. J Spinal Cord Med. 2012;35(4):229-239.

11. Nijendijk JH, Post MW, van Asbeck FW. Epidemiology of traumatic spinal cord injuries in The Netherlands in 2010. Spinal Cord. 2014;52(4):258-263.

12. Montoto-Marqués A, Ferreiro-Velasco ME, Salvador-de la Barrera S, Balboa-Barreiro V, Rodriguez-Sotillo A, Meijide-Failde R. Epidemiology of traumatic spinal cord injury in Galicia, Spain: trends over a 20-year period. Spinal Cord. 2017;55(6):588-594.

13. Bárbara-Bataller E, Méndez-Suárez JL, Alemán-Sánchez C, RamírezLorenzo T, Sosa-Henríquez M. [Epidemiology of traumatic spinal cord injury in Gran Canaria]. Neurocirugia (Astur). 2017;28(1):15-21. Spanish.

14. Taşoğlu Ö, Koyuncu E, Daylak R, et al. Demographic and clinical characteristics of persons with spinal cord injury in Turkey: one-year experience of a primary referral rehabilitation center. J Spinal Cord Med. Epub 2016 Oct 20.

15. Chamberlain JD, Deriaz O, Hund-Georgiadis M, et al. Epidemiology and contemporary risk profile of traumatic spinal cord injury in Switzerland. Inj Epidemiol. 2015;2(1):28.

16. Shrestha P, Shrestha S, Shrestha RK. Retrospective study of spinal cord injury patients admitted to spinal injury rehabilitation center, Sanga, Banepa, Nepal. Nepal Med Coll J. 2014;16(2-4):169-172.

17. Sabre L, Pedai G, Rekand T, Asser T, Linnamägi U, Kõrv J. High incidence of traumatic spinal cord injury in Estonia. Spinal Cord. 2012;50(10):755-759.

18. Ning GZ, Yu TQ, Feng SQ, et al. Epidemiology of traumatic spinal cord injury in Tianjin, China. Spinal Cord. 2011;49(3):386-390.

19. Löfvenmark I, Norrbrink C, Nilsson-Wikmar L, Hultling C, Chakandinakira S, Hasselberg M. Traumatic spinal cord injury in Botswana: characteristics, aetiology and mortality. Spinal Cord. 2015;53(2):150-154. 
20. Pickett GE, Campos-Benitez M, Keller JL, Duggal N. Epidemiology of traumatic spinal cord injury in Canada. Spine (Phila Pa 1976). 2006;31(7):799-805.

21. O'Connor RJ, Murray PC. Review of spinal cord injuries in Ireland. Spinal Cord. 2006;44(7):445-448.

22. Sabre L, Remmer S, Adams A, et al. Impact of fatal cases on the epidemiology of traumatic spinal cord injury in Estonia. Eur $J$ Neurol. 2015;22(5):768-772.

23. Wyndaele M, Wyndaele JJ. Incidence, prevalence and epidemiology of spinal cord injury: what learns a worldwide literature survey? Spinal Cord. 2006;44(9):523-529.

24. New PW, Baxter D, Farry A, Noonan VK. Estimating the incidence and prevalence of traumatic spinal cord injury in Australia. Arch Phys Med Rehabil. 2015;96(1):76-83.

25. Knútsdóttir $\mathrm{S}$, Thórisdóttir H, Sigvaldason K, Jónsson H Jr, Björnsson A, Ingvarsson P. Epidemiology of traumatic spinal cord injuries in Iceland from 1975 to 2009. Spinal Cord. 2012;50(2):123-126.

26. Rahimi-Movaghar V, Saadat S, Rasouli MR, et al. Prevalence of spinal cord injury in Tehran, Iran. J Spinal Cord Med. 2009;32(4): 428-431.

27. New PW, Farry A, Baxter D, Noonan VK. Prevalence of non-traumatic spinal cord injury in Victoria, Australia. Spinal Cord. 2013;51(2): 99-102.

28. Oteir AO, Smith K, Stoelwinder JU, Cox S, Middleton JW, Jennings PA. The epidemiology of pre-hospital potential spinal cord injuries in Victoria, Australia: a six year retrospective cohort study. Inj Epidemiol. 2016;3(1):25.

29. Lehre MA, Eriksen LM, Tirsit A, et al. Outcome in patients undergoing surgery for spinal injury in an Ethiopian hospital. J Neurosurg Spine. 2015;23(6):772-779.

30. Vitale MG, Goss JM, Matsumoto H, Roye DP, Jr. Epidemiology of pediatric spinal cord injury in the United States: years 1997 and 2000. J Pediatr Orthop. 2006;26(6):745-749.

31. Katoh S, Enishi T, Sato N, Sairyo K. High incidence of acute traumatic spinal cord injury in a rural population in Japan in 2011 and 2012: an epidemiological study. Spinal Cord. 2014;52(4):264-267.

32. Alshahri SS, Cripps RA, Lee BB, Al-Jadid MS. Traumatic spinal cord injury in Saudi Arabia: an epidemiological estimate from Riyadh. Spinal Cord. 2012;50(12):882-884.

33. Javadi M, Hafezi-Nejad N, Vaccaro AR, Rahimi-Movaghar V. Medical complications and patient outcomes in Iranian veterans with spinal cord injury. Adv Clin Exp Med. 2014;23(2):269-275.

34. Thompson C, Mutch J, Parent S, Mac-Thiong JM. The changing demographics of traumatic spinal cord injury: an 11-year study of 831 patients. J Spinal Cord Med. 2015;38(2):214-223.

35. Sothmann J, Stander J, Kruger N, Dunn R. Epidemiology of acute spinal cord injuries in the Groote Schuur Hospital Acute Spinal Cord Injury (GSH ASCI) Unit, Cape Town, South Africa, over the past 11 years. S Afr Med J. 2015;105(10):835-839.

36. Bellucci $\mathrm{CH}$, Castro Filho JE, Gomes CM, et al. Contemporary trends in the epidemiology of traumatic spinal cord injury: changes in age and etiology. Neuroepidemiology. 2015;44(2):85-90.

37. Dryden DM, Saunders LD, Rowe BH, et al. Depression following traumatic spinal cord injury. Neuroepidemiology. 2005;25(2):55-61.

38. Shin JC, Kim DH, Yu SJ, Yang HE, Yoon SY. Epidemiologic change of patients with spinal cord injury. Ann Rehabil Med. 2013;37(1):50-56.

39. Dryden DM, Saunders LD, Rowe BH, et al. The epidemiology of traumatic spinal cord injury in Alberta, Canada. Can J Neurol Sci. 2003;30(2):113-121.

40. Jain NB, Ayers GD, Peterson EN, et al. Traumatic spinal cord injury in the United States, 1993-2012. JAMA. 2015;313(22):2236-2243.
41. Kristinsdottir EA, Knutsdottir S, Sigvaldason K, Jonsson H, Jr, Ingvarsson PE. [Epidemiology of spinal cord injury in Iceland from 1975 to 2014]. Laeknabladid. 2016;102(11):491-496. Icelandic.

42. Knox J. Epidemiology of spinal cord injury without radiographic abnormality in children: a nationwide perspective. $J$ Child Orthop. 2016;10(3):255-260.

43. Æsø MS, Solvang SH, Grønning M, Rekand T. Epidemiology of persistent iatrogenic spinal cord injuries in Western Norway. Brain Behav. 2016;6(10):e00522. eCollection 2016.

44. McKinley WO, Seel RT, Hardman JT. Nontraumatic spinal cord injury: incidence, epidemiology, and functional outcome. Arch Phys Med Rehabil. 1999;80(6):619-623.

45. Ning GZ, Mu ZP, Shangguan L, et al. Epidemiological features of traumatic spinal cord injury in Chongqing, China. J Spinal Cord Med. 2016;39(4):455-460.

46. Chen Y, Tang Y, Allen V, DeVivo MJ. Fall-induced spinal cord injury: external causes and implications for prevention. J Spinal Cord Med. 2016;39(1):24-31.

47. Wang CM, Chen Y, DeVivo MJ, Huang CT. Epidemiology of extraspinal fractures associated with acute spinal cord injury. Spinal Cord. 2001;39(11):589-594.

48. Devivo MJ. Epidemiology of traumatic spinal cord injury: trends and future implications. Spinal Cord. 2012;50(5):365-372.

49. Garshick E, Kelley A, Cohen SA, et al. A prospective assessment of mortality in chronic spinal cord injury. Spinal Cord. 2005;43(7):408-416.

50. McCaughey EJ, Purcell M, Barnett SC, Allan DB. Spinal cord injury caused by stab wounds: incidence, natural history, and relevance for future research. $J$ Neurotrauma. 2016;33(15):1416-1421.

51. Majdan M, Brazinova A, Mauritz W. Epidemiology of traumatic spinal cord injuries in Austria 2002-2012. Eur Spine J. 2016;25(1):62-73.

52. Chen Y, He Y, DeVivo MJ. Changing demographics and injury profile of new traumatic spinal cord injuries in the United States, 1972-2014. Arch Phys Med Rehabil. 2016;97(10):1610-1619.

53. Selassie A, Cao Y, Saunders LL. Epidemiology of traumatic spinal cord injury among persons older than 21 Years: a population-based study in South Carolina, 1998-2012. Top Spinal Cord Inj Rehabil. 2015;21(4): 333-344.

54. Saunders LL, Selassie A, Cao Y, Zebracki K, Vogel LC. Epidemiology of pediatric traumatic spinal cord injury in a population-based cohort, 1998-2012. Top Spinal Cord Inj Rehabil. 2015;21(4):325-332.

55. Mathur N, Jain S, Kumar N, Srivastava A, Purohit N, Patni A. Spinal cord injury: scenario in an Indian state. Spinal Cord. 2015;53(5):349-352.

56. Nwankwo OE, Uche EO. Epidemiological and treatment profiles of spinal cord injury in southeast Nigeria. Spinal Cord. 2013;51(6):448-452.

57. Ibrahim A, Lee KY, Kanoo LL, et al. Epidemiology of spinal cord injury in Hospital Kuala Lumpur. Spine (Phila Pa 1976). 2013;38(5):419-424.

58. Chen Y, Tang Y, Vogel LC, Devivo MJ. Causes of spinal cord injury. Top Spinal Cord Inj Rehabil. 2013;19(1):1-8.

59. Wu Q, LiYL, Ning GZ, et al. Epidemiology of traumatic cervical spinal cord injury in Tianjin, China. Spinal Cord. 2012;50(10):740-744.

60. Hasler RM, Exadaktylos AK, Bouamra O, et al. Epidemiology and predictors of spinal injury in adult major trauma patients: European cohort study. Eur Spine J. 2011;20(12):2174-2180.

61. Yousefzadeh Chabok S, Safaee M, Alizadeh A, Ahmadi Dafchahi M, Taghinnejadi O, Koochakinejad L. Epidemiology of traumatic spinal injury: a descriptive study. Acta Med Iran. 2010;48(5):308-311.

62. Qureshi MA, Khalique AB, Pasha IF, et al. Epidemiology of nondisaster spinal injuries at a spine unit. J Coll Physicians Surg Pak. 2010;20(10):667-670.

63. O'Connor P. Incidence and patterns of spinal cord injury in Australia. Accid Anal Prev. 2002;34(4):405-415. 
Journal of Neurorestoratology

\section{Publish your work in this journal}

The Journal of Neurorestoratology is an international, peer-reviewed, open access online journal publishing original research and review articles on the subject of Neurorestoratology. To provide complete coverage of this revolutionary field the Journal of Neurorestoratology will report on relevant experimental research, technological advances, and clinical achievements. The manuscript management system is completely online and includes a very quick and fair peer-review system, which is all easy to use. Visit http://www.dovepress.com/testimonials. php to read real quotes from published authors.

Submit your manuscript here: https:/www.dovepress.com/journal-of-neurorestoratology-journal 